\title{
What is Same but Different and why does it matter?
}

\begin{tabular}{c}
\hline JENNIFER L. BIDDLE \\
NATIONAL INSTITUTE FOR EXPERIMENTAL ARTS, \\
UNSW ART \& DESIGN, \\
UNIVERSITY OF NEW SOUTH WALES \\
AND \\
LISA STEFANOFF \\
NATIONAL INSTITUTE FOR EXPERIMENTAL ARTS, \\
UNSW ART \& DESIGN, \\
UNIVERSITY OF NEW SOUTH WALES
\end{tabular}

These technologies that are coming into our communities; we need to exploit them and use them how we want to use them. To record, transcribe, translate our Jukurrpa, our history. Most people, normal Australians, haven't seen our culture for what it is-what it is really ... Importantly it is made by our own people for our own people.

This special section of Cultural Studies Review brings together a select series of multi-media presentations originally delivered at two one-day forums titled Same ISSN 1837-8692

Cultural Studies Review 2015. ( 2015 Jennifer L. Biddle and Lisa Stefanoff. This is an Open Access article distributed under the terms of the Creative Commons Attribution 4.0 Unported (CC BY 4.0) License (https://creativecommons.org/licenses/by/4.0/), allowing third parties to copy and redistribute the material in any medium or format and to remix, transform, and build upon the material for any purpose, even commercially, provided the original work is properly cited and states its license. 
but Different: Experimentation and Innovation in Desert Arts, which were held in Alice Springs in 2012 and 2013. We begin by paying our respects to the traditional owners and custodians of the country that Same but Different took shape within, the Central Arrernte people of Mparntwe/Alice Springs. Thank you for hosting Same but Different on your lands.

Same but Different, the first national forum on experimentation in Central and Western Desert arts, was developed as a partnership between research scholars Jennifer Biddle and Lisa Stefanoff, in association with Desart Inc., the desert art centres' representative body. The first Same but Different event, held at the Desert Knowledge Precinct (DKP) in 2012, brought together eleven different arts organisations, representing thirteen different language groups, with art sector and research colleagues, and community associates, to create a new space for engagement, communication, partnership and exchange. Feedback from participants in this first forum was overwhelmingly positive, and a second Same but Different was held, again in Alice Springs at the DKP, in April 2013. This was followed by a curated evening of screenings of new, experimental Indigenous animation works, Desert Animations, which premiered in Sydney at the National Institute for Experimental Arts, UNSW, before touring nationally and internationally, including a screening at the 2014 American Anthropological Association annual meeting in Washington DC. In 2015, Same but Different has expanded to incorporate a multiplatform national exhibition, an artist-in-residency program (at Cicada Press, UNSW) and a symposium held at Galleries UNSW/NIEA/UNSW Art \& Design, Sydney, under the new title 'We are in Wonder LAND: New Experimental Art from Central Australia'.

What, then, was the rationale behind the establishment of Same but Different? What reasoning is behind this long-term partnership, this platform and its expansion, and in turn, why now this special edited section for Cultural Studies Review? 


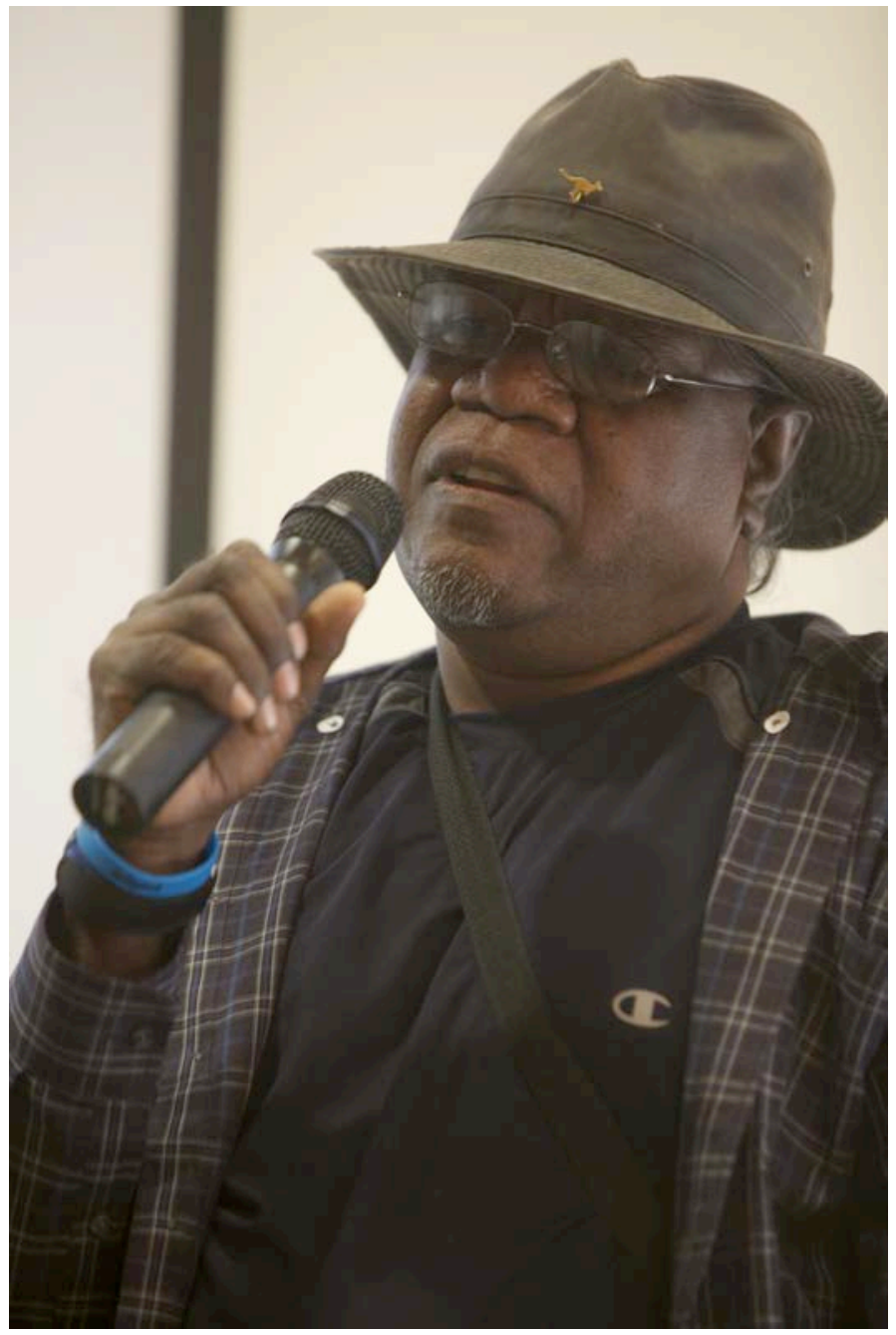

Image 1: Wanta Steve Jampijinpa Patrick, keynote talk, Same But Different 2013, Alice Springs NT (photograph: O. Eclipse; image @ Wanta Steve Jampijinpa Patrick and Same But Different)

$-1$

Same but Different was born out of both intense frustration and excitement. Frustration, in the first instance, because of the relative lack of public awareness of what is arguably some of the most energetic, urgent and significant cultural activity taking shape in Australia today. Beyond the success of the Western Desert painting movement, a new arena of intensive activism and vanguard aesthetics is currently taking shape across the desert, largely absent from national debate and unrecognised by major exhibitions. Art history and analysis has not kept pace with what emergent desert art works demand. ${ }^{2}$ 
An astonishing array of new works in new media is developing, instigating new trajectories of aesthetic tradition and destablising established frameworks: recycled and found object forms, fibre and soft sculpture, short film, animation and digital portraiture, history paintings and works of acrylic witness, and new intercultural ceremony and festival. Quite simply, Same but Different was established to enhance the visibility of this range of exciting new works by creating a networked, Aboriginal artist-centric context for showcasing these vital aesthetics. Desart Inc.'s role (as the peak representative body for desert community art centres) was essential in facilitating Same but Different's unique convention of desert-living Aboriginal art makers, Indigenous artists and curators (based elsewhere), creative producers, activists, cultural researchers and art sector industry colleagues.

Despite a growing number of national indicators attesting to the significance of the burgeoning field of experimental desert arts, ${ }^{3}$ public debate remains mired by tired paradigms and sweeping portraits of 'dying sunset' authenticities and 'end of the Aboriginal art dream' predictions. The media report steep declines continuing in the Australian Indigenous art market in the wake of the global financial crisis. National policy-driven depictions of 'remote' Australia in a crisis state of dysfunction and despair have been, and continue to be, rife. At the time of first drafting this introduction, a national news article on frontline developments bemoaned the passing of the once vibrant 'old Aboriginal art world', depicting the contemporary remote field as a 'fateful journey away from its origins in ceremony and law'; a 'slackening' and 'diluting' of once-was traditional glory.4 In early 2015, The Australian newspaper reported fresh allegations of 'fake' desert canvases circulating in the primary auction and sales market through one active business operating in multiple locations. ${ }^{5}$ The continuity of suspect practices in the industry shakes consumer confidence in an already fragile market.

It is in this context that Same but Different took shape. Our intent was to ask: What might it mean to view Indigenous aesthetics and intercultural cosmopolitanisms not from the entrenched metropolitan perspectives of Sydney, London or New York but from the so-called 'remote' zone, where 'peripheral' artists live and work in communities such as Lajamanu, Amata or the town camps of Alice Springs? What might it mean to take seriously the demands of desert Aboriginal artists to represent themselves and their practice both politically and culturally; to 
develop their own art history, to model distinctive art theory and to shape public debate? How might Indigenous presence, sovereignty and local cultural life world(s) intervene in this tired terrain? How might a new kind of public platform serve to render visible, audible, and palpable the pioneering practices and aesthetic developments taking shape across desert Australia and support the development of a confident market for this new work? What are Desert Aboriginal models of innovation, and why do they matter today?

The nine articles, reports, reviews, interviews, video links and photo essays assembled here are testament to this task. They demonstrate, in any number of ways, that contemporary desert practices are not imprisoned by the past, corrupted by commodification, or indicative of authenticity-at-risk. The moniker Same but Different intentionally cites a Warlpiri-specific understanding of experimentation, derived from the artist Kumanjayi Jampijinpa Robertson, founding director of Warnayaka Art and Cultural Aboriginal Corporation in the 1990s, who described the emergence of acrylic Jukurrpa painting, and his own artistic practice, as not in fact a break with or an abandonment of traditional authority, rather, as 'same but different'. As Indigenous activists, anthropologists and historians have repeatedly argued, it is grotesque ethnocentricism to project a non-Indigenous framework, in which the past and future are sharply cordoned-off from the present, onto an Indigenous present. What uniquely distinguishes Indigenous temporalities are living 'post-present' contiguities, as Hetti Perkins and Victoria Lynn put it many years ago, in which the new is always 'an insurgent act of cultural reiteration'. ${ }^{6}$ The assumption of chronological progression and inevitable historical loss are inadequate paradigms for Indigenous aesthetics, defined instead by complex ways in which both the past and future are activated and enlivened, through aesthetic practice in the present.

In 2008 Wanta Steve Jampijinpa Patrick, keynote speaker at Same but Different in both 2012 and 2013, described his newly conceived, experimental Warlpiri festival Milpirri (combining Jardi-Warnpa ceremony with hip-hop and break dance) thus: 'It was an unseen thing and now it is a seen thing.'7 Patrick's model of aesthetic innovation provided the basis for the developing platform of Same but Different. Namely, a performative realisation of how contemporary desert art mediums and forms, including new media, can enable the revelation of 'tradition'. 


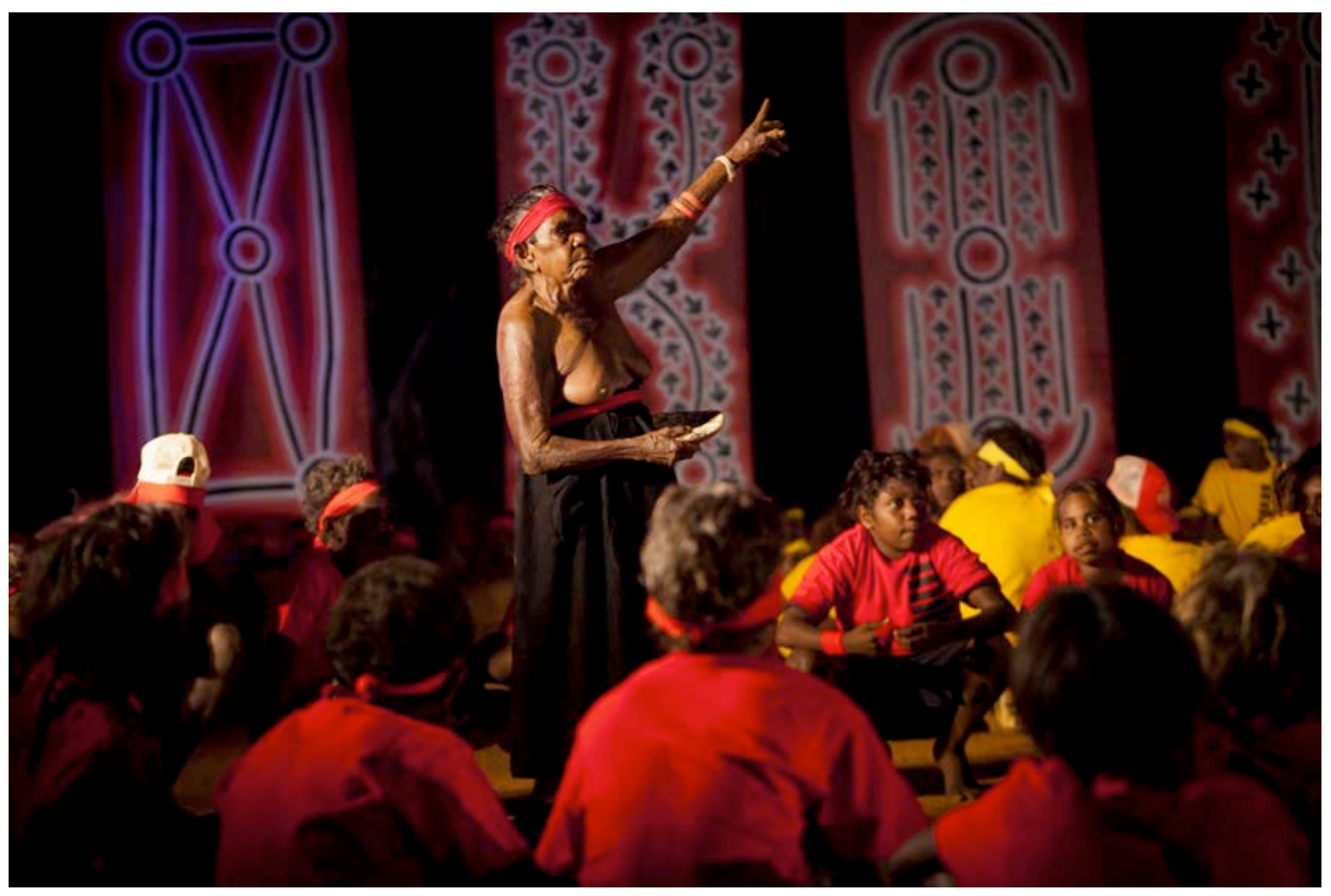

Image 2: Rosie Napurrurla Tasman, Milpirri Festival 2012, Lajamanu, NT (photograph: P. Eve; image (C) Tracks Dance Company 2012)

Counter to the dominant assumption that experimentation or new media are somehow incompatible with or, worse, a threat to vernacular lifeworlds and cultural tradition-as seen in 1980s non-Aboriginal art criticism and fierce debates about the inception of electronic desert broadcast media as a potentially colonising technology-Same but Different set out to explore the ways new mediums are, in fact, facilitating what tradition was and what it might become for the future. ${ }^{8} \mathrm{We}$ wanted to explore why certain media and certain kinds of practice are privileged sites for the revelation of tradition today. What are the significant differences between these new sites and the two dominant Indigenous art movements over the past forty years-acrylic painting movement and Indigenous filmmaking?9

In Same but Different, our understanding of 'art' is neither art historical nor curatorial, in so far as these frameworks tend to privilege end product or objectfocused analyses. Rather, our interests were, from the beginning, in art-making as social practice and cultural process. Thus in the collected contributions, so-called 'background' stories and 'out of exhibition' contexts of contemporary practice outweigh end product 'art' analyses in crucial ways. The pressing issue in emergent 
experimental desert arts practice, as the works here demonstrate, is not documentation or archiving in order to ensure against the risk of cultural loss. Nor is it a matter of how best to 'transfer' tradition to a new medium. Rather, these diverse projects demonstrate the very high degree of ingenuity, commitment and resources required to develop new means and techniques to recreate and re-evoke Jukurrpa/Tjukurpa (Law/ceremony/'Dreaming') in meaningful contemporary ways.

$-11$

The task of producing Same but Different was itself an experimental endeavour. No 'experimental' desert art field exists as such in either publication or practice. There is no community of 'experimental art practitioners' that is analogous to those communities created by the social relatedness of artists or simple proximity. We did not produce the two forums to form an art experimentation-focused community but, rather, to create a provisional chain of events where artists might see each other's most innovative new work, listen to each other's stories, exchange ideas, projects, content and creation, as well as participate in the public performative context of making a new experimental assemblage.

The Central and Western deserts span vast tracts of Western Australia, South Australia and the Northern Territory. Desart Inc. alone supports forty-two distinct Aboriginal community art organisations within its footprint, intersecting at its edges with the APY Lands Art Centres' peak body, Ananguku Arts (KuArts), and the Aboriginal Art Centre Hub WA (ACHWAA). The scope of experimental and innovative desert arts is broad and diverse. The economic, social, cultural and geographical vectors that differentiate art-making contexts-from community art centres to schools, to churches, to private lives (in some cases)-mean there is nothing like a level playing field of experimental practice. There is no singular place, orientation, practice or perspective from which experimentation and innovation emerges. Not one of these practices can, in this sense, stand for or 'represent' the greater field. The works taking shape today are not representations of something else, they are 'the thing' itself.

Despite the wildfire-like increase in internet, digital media and mobile phone usage in the desert10-exemplified by the success of IndigiTUBE (http://indigitube.com.au, also featured in Same but Different 2012), among other 
new online media sites-the so-called 'communication revolution' and its promise of global networked citizenry remain exaggerated. Not only has a 'digital-divide' separated 'urban' from more 'remote' parts of Australia historically, but also regional and remote Australia today remains under-serviced, with radically variant degrees of network access, costs and consistency. Very real distances between communities; diversities of language, cultural practices and histories of occupation; the uneven resourcing of community art centres and project bases; and the time and resource-stretched realities of community lifeworlds each posed concrete challenges in the design and production of the Same but Different events. In both years, the forum was held just before Desart Inc.'s annual two-day art centre conference, which enabled greater participation of desert artists and community members, given their ever-demanding work, conference and exhibition schedules.

How, then, did we engender a context that might serve to facilitate communication and exchange between desert artists and communities, as well as between the desert and the broader national audience? As two non-Aboriginal women working for many years in desert art and media arenas-Jennifer as a cultural-linguistic anthropologist for over twenty years and more recently as an ARC Future Fellow with her project Remote Avant-Garde: Experimental Indigenous Art and Lisa as cultural anthropologist living in the Central Desert and a collaborative media/arts producer for a decade-we developed the Same but Different initiative first through established relationships and networks. We consulted key artists and community arts organisations that we knew well. Our collaboration with Desart Inc. was crucial. The appointment of Philip Watkins as Desart Inc. executive officer in 2010, combined with the fresh re-branding of Desart Inc. as an organisation focused on putting 'Culture First', provided for rich collaborative possibilities. Watkins's public insistence on the survival of the 'shared dream of a thriving, sustainable Aboriginal art sector' despite the fact that 'high end galleries specializing in Indigenous art may be on their knees'11 made for a strong basis from which to develop the Same but Different partnership.

The CRC for Remote Economic Participation 'Aboriginal and Torres Strait Islander Art Economies' project (where Lisa was based as a researcher 2011-2012), the Desert Aboriginal media organisations Pintubi Anmatjere Warlpiri (PAW) Media and Central Australian Aboriginal Media Association (CAAMA) were also key 
partners, providing a physical venue for the events, human resources and documentation of both Alice Springs forums. We worked together to see how we could engender a formally and institutionally enduring, and open-ended, partnership that might constitute a new kind of network, driven by Aboriginal people, priorities and orientations, rather than the kind of abstract or ready-made spectacle determined externally by Eurocentric modes of representation (as an art historical approach might achieve). We aimed to convene a heterogeneous gathering of artists in desert country and to provide a space for artists and community members to showcase multiple art forms in diverse multi-sensory performative capacities of people and projects occupying real time and space, with capacity for multi-media presentations; where experimental and innovative cultural creators could take possession of the forum to present their own works and agendas, in their own terms, models and language (via interpreters in some cases).

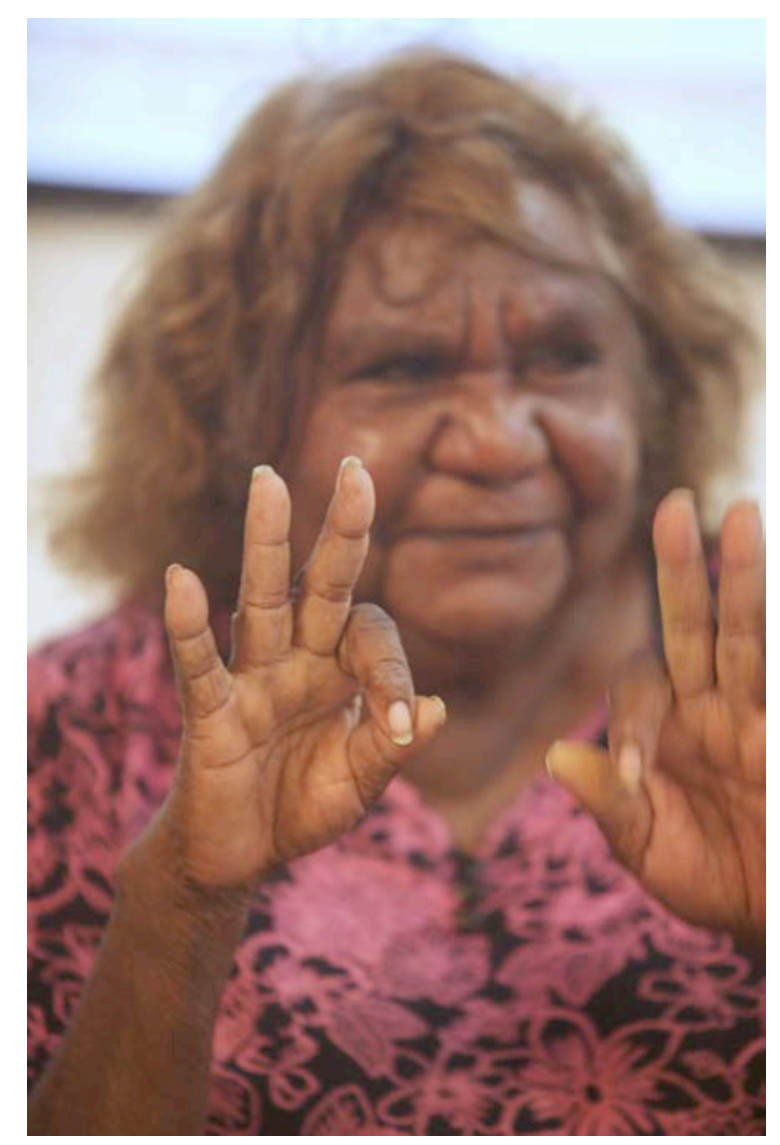

Image 3: Clarrie Kemarr, Embodied Language, Same But Different 2013, Alice Springs NT (photograph: O. Eclipse; image @ Clarrie Kemarr and Same But Different) 
As we hoped, Indigenous participants outnumbered non-Indigenous participants at both forums. The formats for presentation were determined by artists, art centres and community members, and took radically differing shapes. In 2012, the event unfolded from a singular lecture format by Wanta Steve Janpijinpa Patrick (see Patrick, this volume), to include a polyvocal bilingual slideshow with spontaneous inma (song, dance, ceremony) (Tjanpi Desert Weavers, this volume), a pre-recorded video address by Curtis Taylor (see Taylor, this volume) combined with a presentation on the multi-award winning Canning Stock Route project (Davenport Acker, this volume), an online media tour of IndigiTube by Joel Ken (IRCA), an introduced screening of soft sculpture stop-motion animation from the Yarrenyty Arltere Art Centre in Larapinta Valley town camp, Alice Springs (Yarrenyty Arltere Artists, this volume), screenings and presentations on stop-motion paper and claymation animation (PAW Media in Yuendumu) and fibre art animation by young and senior Alywarr and Anmatyerre artists from the Batchelor Institute for Indigenous Tertiary Education (BIITE) discussed by Aboriginal scholar Josie Douglas; a presentation by Brenda Croft of the beginnings of her arts-history-auto ethnographic PhD project 'Gurindji, Still on My Mind' (see Croft, this volume), video presentations on emergent textually inscribed narrative canvas painting at Tangentyere Artists (Tangentyere Artists, this volume) and innovation in curatorial practice by Indigenous curator and arts writer Djon Mundine, and an industry discussion group on the 'money story' in producing experimental and innovative desert arts.

The 2013 forum program featured visiting Yolgnu artists Yinimala Gumana and Wukun Wanambi (Buku Larrnggay and Mulka Media Centre) presenting on found object sculpture, new media and emerging painting; a video conversation about Martu and non-Aboriginal collaboration in Curtis Taylor and Lily Hibbert's installation Phone Booth; a demonstration of desert sign language and its new digital archive Iltyem-Iltyem - A Website for Sign Language; a skyped conversation between Art Gallery of South Australia curator Lisa Slade and Tjala Artists on artist-led curatorial practices; senior Aboriginal Arrernte/Kalkadoon curator Hetti Perkins discussing emerging Aboriginal public art in Australian and international urban landscapes and a live digital graphic art demonstration by the young 'Satellite Sisters' Layla Walker and Alison Lockyer from Big hART's NEOMAD/Yijala Yala 


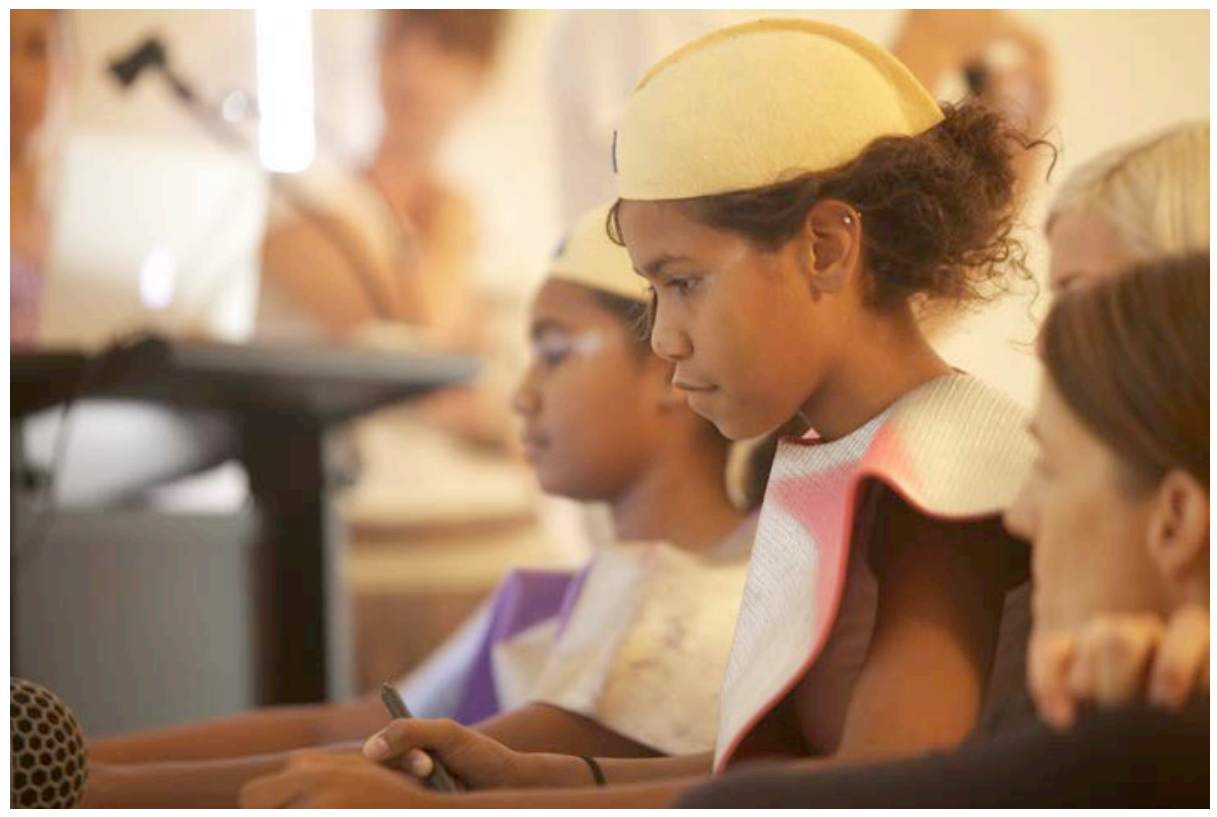

Image 4: Layla Walker and Alison Lockyer give a demonstration, Love Punks, Same But Different 2013, Alice Springs NT (photograph O. Eclipse; image @ Layla Walker, Alison Lockyer and Same But Different)

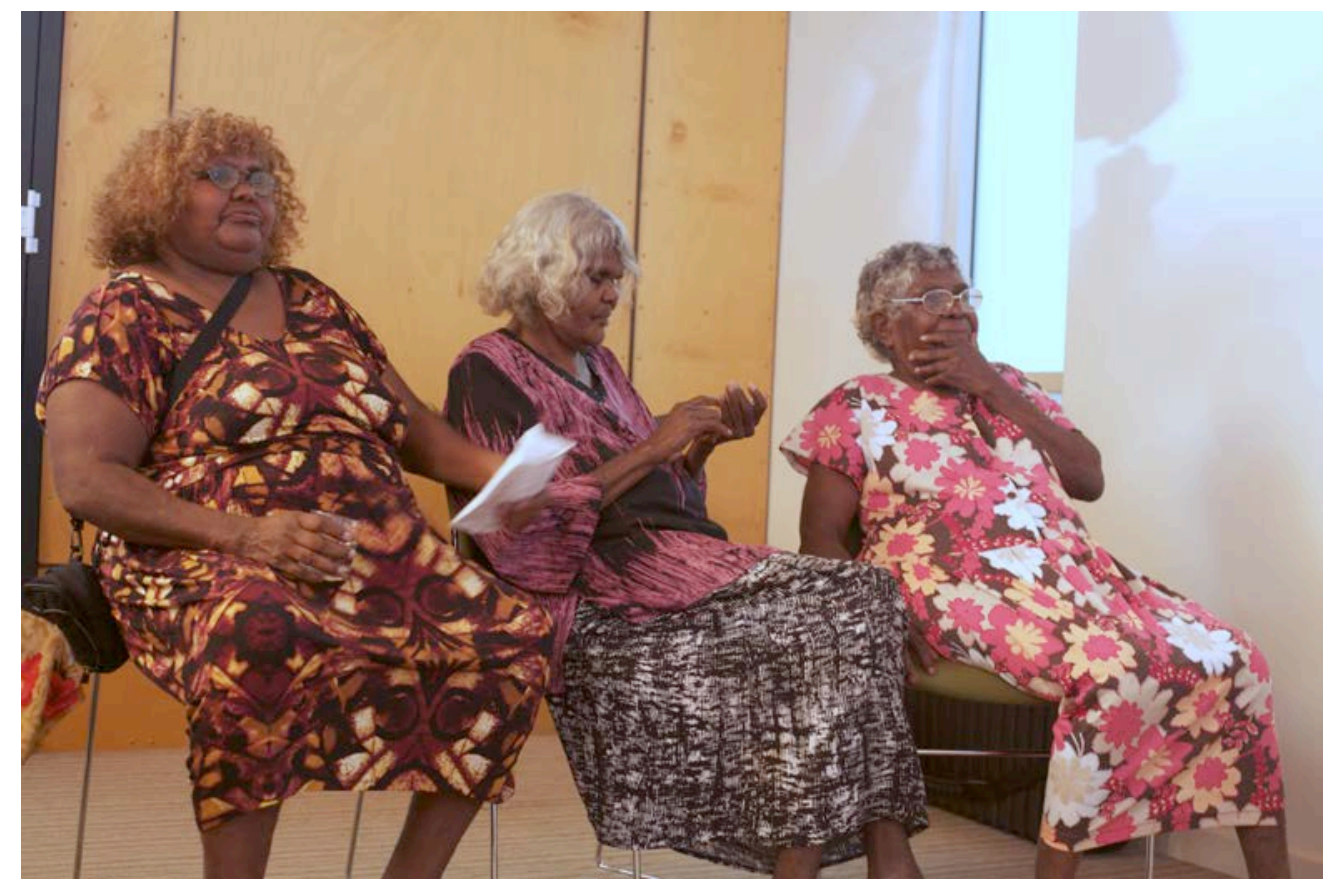

Image 5: Tjanpi Desert Weavers, Yaritji Young, Nyurpaya Kaika Burton, Ilawanti Ungutjuru Ken, Tjala Arts, Same But Different 2013, Alice Springs NT (photograph: O. Eclipse; image (C) Yaritji Young, Nyurpaya Kaika Burton, Ilawanti Ungutjuru Ken and Same But Different) 
project in Roebourne, Western Australia (see Myers, this volume). This multiplatform design was met with great interest by its audience (largely comprised of artists and other art community members); in both years, many stayed overtime in the crowded and ultimately overheated room. We were, and we remain, humbled by the enthusiastic attendance of artists and wish to graciously extend our deep appreciation to all who came together across long desert distances to share their work and skills in this new, lively and experimental convention of colleagues, associates, friends, relations and strangers. We thank the selection of presenters from both years of Same but Different who have contributed work to this special section.

- III

As the presentations collected here demonstrate, far more is being made-and being made to matter-in new arts-cultural practices taking shape today than might be reduced to a 'portable, durable, frame-able, collectable'12 piece of Aboriginal material culture recognised as 'high', 'primitive', or 'ethnographic' art. Some of the artworks presented through Same but Different have enjoyed exposure in high-end art market contexts, but not all have, and nor are their objectives and 'value' necessarily to be framed in this manner.

Milpirri (see Patrick, this volume) remains a fiercely Lajamanu-Warlpiri localised festival, serving specific Lajamanu-Warlpiri determined aspirations, despite multiple invitations for it to tour nationally or morph into a larger event. The aim of the ground-breaking Canning Stock Route project (Davenport-Acker, this volume), resulting in the major national exhibition Yiwarra Kuju and archive held at the National Museum of Australia (note, not art gallery), was both greater than, and different from, a curated show of exhibition art objects. ${ }^{13}$ Over a six-year period, involving seventeen Aboriginal communities, and fifty-eight different workshops, as project media-maker Curtis Taylor puts it, Canning Stock Route/Yiwarra Kuju was really about 'community, collaboration and reconciliation ... two way learning ... a chance to listen to each other, work and learn from each other.' (Taylor in Davenport Acker, this volume).

Not all of the practices gathered in Same but Different call themselves 'art'. Milpirri (Biddle with Tracks, this volume) has struggled historically with what to call 
itself in English: 'festival', 'event', 'ceremony', 'ritual', 'performance', 'dance', 'theatre', 'visual spectacular', or all or none of the above? The online graphics of the Big hART Yijala Yala (Myers, this volume) project's NEOMAD Love Punks kicks 'art' to playful space-trips infecting the twilight-zone cusps of bilingual/biliteracy educational new media, video game and comic book all at once. Tjanpi Desert Weavers' (this volume) grass, raffia and coloured wool sculptures refuse categorical delineations of 'art' or 'craft' to literally 'take off' (paarparkanyi) somewhere else altogether, looping back to desert camps through song, dance and story (Jukurrpa), if landing, only to take flight seemingly yet again, in exhibition at Tandanya's 'Deadly: Between Heaven and Hell' (2011). Artist-curator-scholar Brenda L. Croft's (this volume) 'Still in my Mind', an auto-ethnographic collaboration, combines academic research with community art-making in order to make a history in the future that does not yet exist in the past. Through collaboration between Gurindji diaspora living away from country and Gurindji community residents in Daguragu/Kalkaringi/Wave Hill, Croft creates images of a 'community' and 'identity' not simply present in any one place or person, confounding colonial temporalities and boundaries, and harnessing art to the creative necessity required to challenge the archive's sovereign claim to 'the real'.

The value of these practices cannot be assessed in the dominant terms of neoliberal state prescriptions for the commodification of culture, so often proposed uncritically as the basis for variants of the dream of 'sustainable [remote] community development'. The cultural forms canvassed in Same but Different are situated in concrete entanglements with complex lifeworld circumstances and contingencies. Practice-driven and socially based, these arts support and facilitate the maintenance of at-risk vernacular languages, threatened traditions and intangible cultural heritage. The crucial 'histories of Aboriginal futures' undertaken by these projects, are only achievable with 'great difficulty, struggle, imagination and the mobilizing of a myriad of cultural resources'.14 Taking shape in unstable and unwieldy intercultural zones, these are 'frontier' art forms. They flag the limits of the canvas-dominated Indigenous Australian art market and open horizons to new transmutations of aesthetic heritage (as discussed by artists and AGSA curator Lisa Slade at Same but Different 2013). They are what we might call a 'remote avant- 
garde': the material becomings of cultural survival, shaped in and by, and in turn shaping, new interstices of form, expectation and aesthetic 'movement'.

Progressive collaborative curatorial practice, as exemplified by the Art Gallery of South Australia's work with both Tjanpi and Tjala Arts in recent exhibitions and the National Museum of Australia's collaborative curation of the Canning Stock Route/Yiwarra Kuju project, welcomes these works and their makers at a pace unmatched by the established art market (see Davenport-Acker, this volume). Not only do the innovative works assembled as Same but Different defy familiar conventions of the market-destined Desert Aboriginal art commodity, their exhibition practice ensures the instigation of ways of thinking, feeling and being that cannot be readily assimilated. ${ }^{15}$ As this special section of Cultural Studies Review, available as a digital form itself, explores, these arts insist on new frameworks and new visibilities, both practically and conceptually.

\section{$-\mathrm{IV}$}

There is a final rationale for Same but Different as a project, and for its appearance in this publication, in this second decade of the twenty-first century. The initiative has taken shape in a harsh spotlight of national Indigenous affairs. Since 2007, under new Australian government policy, 'remote' Aboriginal Australia has been accused of, and held responsible for, a host of crippling socioeconomic problems. Heightened state discipline and new bureaucracies of surveillance have been instituted to oversee the Northern Territory's 'remote' communities. In this climate and in the absence of regular responsible media analysis, new desert art provides a primary Aboriginal witness to other realities.

Social distress and state power, witnessed by those who experience it directly (rather than by those who make laws they are not themselves bound to endure) are crucial thematics for some of Alice Springs' Tangentyere artists. Their new 'documentary paintings' that have taken shape since 2005 exemplify intimate insider visions of lives in cultural transition to provide bold pictorial and textual commentary against the white noise of mainstream journalism and non-Aboriginal representations of Alice Springs town camp and remote community life. Contemporary desert art is, arguably, 'art under occupation'; an art of necessity and survival. ${ }^{16}$ Same but Different provides a positive reconfiguration of the distressed 
'remote', identifying the importance of innovative, expressive cultural practice both as a primary means for contemporary local self-representation and as a material means for continuing ways of doing and being otherwise silenced, marginalised or disavowed.

Arts and crafts from Alice Springs' town camps are defining in this sense. Since its inception, Yarrenyty Arltere Artists, part of the Yarrenyty Arltere Learning Centre established in 2000 at Larapinta Valley town camp, has, for example, worked closely with community members to develop works of high sociocultural relevance through radical innovation in local culture. From hand-dyed silk scarves (coloured with the pigments of locally gathered native vegetation: eucalyptus, salt bush, mistletoe, puff mushroom, as well as residue from local rusted metal refuse, matchstick heads, orange peel and tea) to the soft sculptural works of recycled blankets and handstitched embroidery, to stop-motion animated short films, this art supports the maintenance of marginalised town camp lifeworld capacities. It offers practicebased ways in which collective art making can be 'healthy-making'. As the Yarrenyty Arltere Artists (this volume) describe, the art centre of Yarrenyty Arltere provides a new space for future-making.

Contemporary political discourse on 'the problem' of 'remote' Aboriginalityits past, present and future-finds it hard to imagine desert communities as economically viable or healthy places for human lives, without radical social intervention and change. ${ }^{17}$ Current policy implicitly urges Indigenous Australians to pursue economic livelihood 'opportunities' away from their homes, in order to simultaneously improve economic wellbeing and to contribute to (so-called) greater Australian society as economically productive citizens. Within this framework, traditional economic practices, societal dynamics and language itself, are seen as obstacles to these objectives. The capacities for 'culture' to inform and enhance remote economic possibilities, through art-based practices, have long been promoted as development 'solutions', but all too often with unrealistic expectations. 'Art' has at many times been posited as a single industry 'solution' for remote communities, with little comprehension of the limited potential of commodity 'art' $n$ a speculative and fragile market. Rarely is the 'value' of art making in relation to community sustainability demonstrated through empirical data or analysis despite 
the strong evidence of its social impacts, apparent in art centres' promotions, public presentations, reports and grant writing. ${ }^{18}$

In this context, this guest-edited section can itself be understood as an intervention in the non-consultative and top-down tendencies of current national policy and debate. As a nationally funded research-based initiative, Same but Different aims to create a new framework for 'remote' desert Aboriginal selfpresentation. ${ }^{19}$ The project is, moreover, located within the terms of key conversations in Indigenous studies. Pat Dodson's inaugural speech launching the UNSW Indigenous Policy and Dialogue Research Unit in 2009, an original inspiration for this long-term initiative, focused on the need for new forms of collaboration between remote, community-based projects and university research. Such initiatives would, he suggested, need to take shape at the local and the regional level because local communities are far too often excluded from discussion and debate about issues and matters that affect their lives most. New kinds of initiatives are urgently

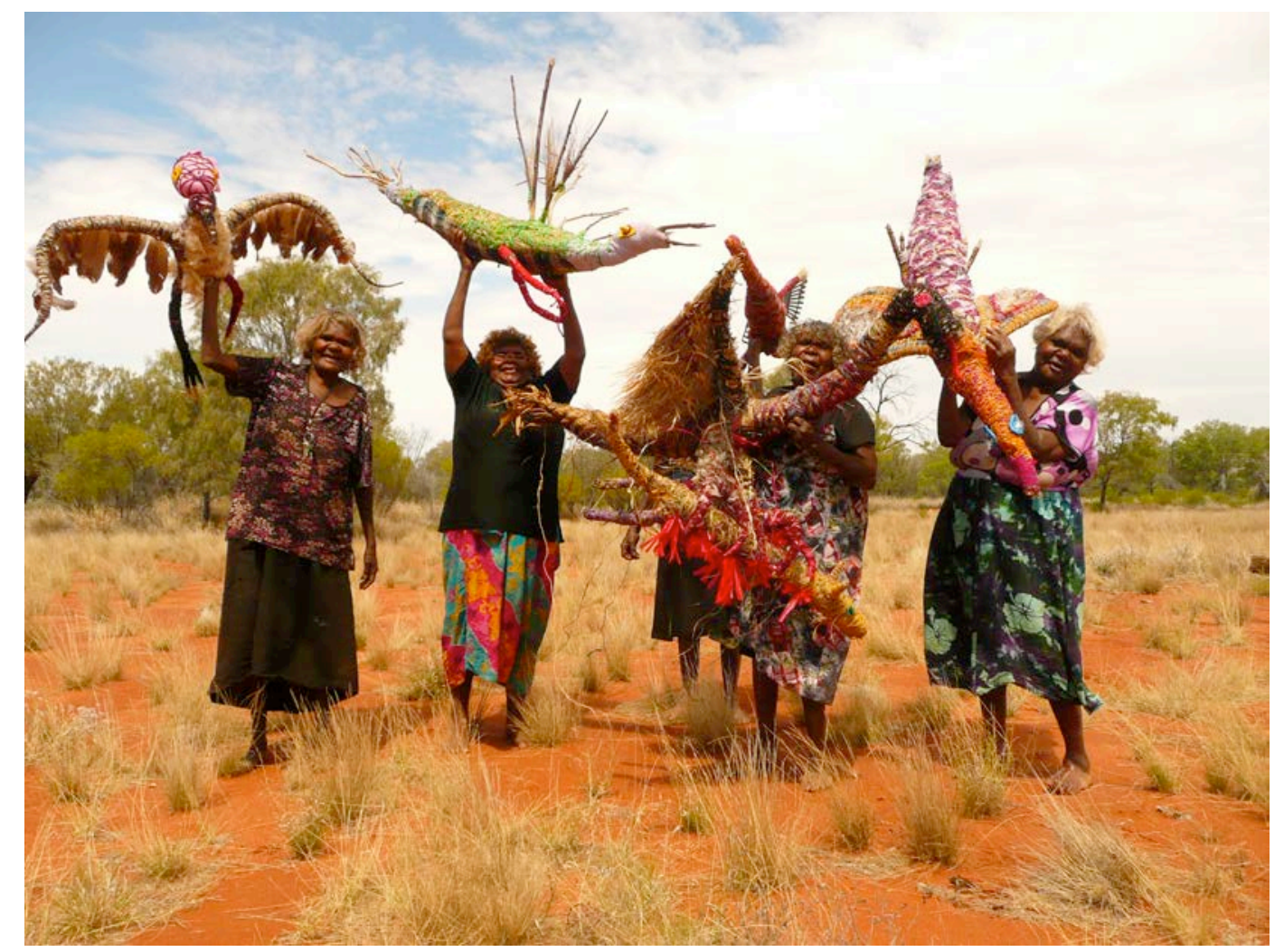

Image 6: Tjanpi Desert Weavers with their works, artists camp near Amata, SA (photograph J. Foster; image (C) NPY Women's Council 2011) 
required, Dodson argued, that show how living in the bush is 'an advantage, not an impediment' to Aboriginal futures today. Same but Different proposes such a context.

$-\mathrm{V}$

We have aimed to make this edited section as visually exciting, image-driven and diverse in performative style as the Same but Different forums were, with contributions appearing in a number of formats. These range from bilingual transcription and direct translation of a group presentation based on a painting and a dance performance (Tjanpi), to a written-to-be-spoken collaboration 'finding a way to tell their story that does not give away everything at once' (as Yarrenyty Arltere artists state); from Curtis Taylor's video address to the forum, to a postforum discussion between Jennifer Biddle and the directors of Tracks Dance Company. We thank the editorial team of Cultural Studies Review for generously taking up the challenge of publishing a collection of works that, like their authors, challenge academic expectations and frameworks. We hope that the multi-genre and mixed-media format of this collection might make it possible for these works to be heard in at least something like the ways in which they were presented; judged not by their textual status alone but as performances with phenomenological density, in which aural, sonic, visual and haptic qualities (as the photographs and video links provide) might amplify a more immersive aesthetic experience, rather than a strictly analytic 'reading'.

If innovative and experimental new desert arts are indeed 'same but different' - an illuminated helix twisting of what matters in desert lifeworlds today into new matter-this special section might itself be thought of as one of these new material refractions. It is a text for re-imagining what tjanpi, and raffia, old blankets and new stitches, paint and canvas, video and hip hop and iPad apps and old stories, ancestors and archives and language and Law might look like, sound like, feel like another time again today, as new artists engage the past on their way to making future heritage today.

It needs to be stressed that this section is neither a representational nor a democratic 'survey' of all the experimental and innovative arts developments presently taking shape across the desert. Nor should it be read as such. Rather, like 
the forums from which it emerged, this collection is partial, contingent, selective. An experiment itself, it is what Ranciere might describe as 'a new adventure in a new idiom' whose ultimate effects cannot be anticipated in advance. ${ }^{20}$ In staging as it does a new assemblage for the first time, it equally requires a new and active form of engagement and interaction in which these works might not simply be perceived as sheer ethical testimony to an on-stage hyper-consumable 'new', but a more open and active participation in a larger new open collectivity yet in the making. We hope that you enjoy your engagements with the essays, images and videos that follow, and we welcome your responses as part of the ongoing shaping of the Same but Different project.

This introduction was drafted in 2014. A year later, as this issue is going to press in 2015, the Australian Prime Minister Tony Abbott has announced his support for the Western Australian government's plan to close half of that state's 274 'remote' Aboriginal communities (in line with Commonwealth Government withdrawal of state funding for 'remote' primary services). Prime Minister Abbott's support for the WA decision took the form of offensive defence; blaming Aboriginal people for the dire consequences of what he called a 'lifestyle choice' to live where there are no schools, no jobs, and no capacity, in his terms, for 'full participation in Australian society'. Noel Pearson called the Prime Minister's comments 'deranged'. ${ }^{21}$ Deploying the concepts 'lifestyle' and 'choice' in this assessment is a pernicious move: it masks the fact that the 'problem' at hand is indeed the Commonwealth Government's and Western Australia's refusal to provide basic services afforded to all other Australians. It abnegates the fact that many Aboriginal people live on sovereign territory; Aboriginal country by right and in many cases by Australian law (under state and territory Land Rights Acts and national Native Title Legislation). Obligation, responsibility and duty to hold country, to hear, listen and respond to it properly, is not a matter of neoliberal 'choice'. As Wanta Steve Jampijinpa Patrick (this volume) describes it, responsibiity to country is precisely what is required to be 'Australian' today, 
The art featured in this special edition attests to the vital importance of living relationships to country, place and ways of being that are under threat in this political climate. If the language of 'choice' is encrusted as the dominant paradigm of our age, a discursive iron cage to be sure, desert community artists are demonstrating, through their ongoing energetic practice and commitments to cultural survival, that no one chooses or can choose to leave Country, to sever their lived custodial relationships with it or to abandon their greater responsibilities for its wellbeing.

Jennifer Biddle is Senior Research Fellow and Director of Visual Anthropology \& Visual Culture at the National Institute for Experimental Arts (NIEA), UNSW Art \& Design. She is an anthropologist of art, language and emotion, and has worked in Central Australia for over two decades. Her most recent book is Remote Avant-garde: Aboriginal Art under Occupation (forthcoming). In 2015 she curated the exhibition 'We are in Wonder LAND: new experimental art from Central Australia' (UNSW Galleries) with Philip Watkins (Desart Inc. EO) and Lisa Stefanoff and with curatorial advisor Brenda L. Croft.

Lisa Stefanoff lived in Alice Springs from 2002 to 2012, working as a research anthropologist, screen producer and editor at CAAMA, IAD Press and on the CRC for Remote Economic Participation's Aboriginal and Torres Strait Islander Art Economies project. During this time she was also an independent art, radio and film producer and screen curator. Currently based in Darwin, she is an ARC Post-doctoral Research Fellow at NIEA UNSW Art \& Design working on a collaborative artspractice led new media research project with desert women artists. In 2015 she curated the exhibition 'We are in Wonder LAND: new experimental art from Central Australia' (UNSW Galleries) with Philip Watkins (Desart Inc. EO) and Jennifer Biddle and with curatorial advisor Brenda L. Croft.

-ACKNOWLEDGEMENTS

Jennifer L. Biddle \& Lisa Stefanoff-What is Same but Different? 115 
Presentations from the 2012 Same but Different: Experimentation and Innovation in Desert Arts forum were recorded and hosted online by PAW Media and can now be found at $<$ https://vimeo.com/53907819>. Same but Different (II) 2013 forum presentations were recorded by CAAMA and will be made available online in 2015 .

Same but Different: Experimentation and Innovation in Desert Arts is a collaboration between Desart Inc., and the National Institute for Experimental Arts (UNSW Art and Design, formerly College of Fine Arts (COFA), UNSW), co-convened and co-curated by Dr Jennifer Biddle and Dr Lisa Stefanoff, made possible through generous support from the Australian Research Council, COFA/UNSW Faculty Research Conference Grant and the National Institute of Experimental Arts, COFA, UNSW; with additional partnerships with CRC-REP/Ninti One Ltd, PAW Media, CAAMA and support from ArtsNT and CountryArts WA. The editors would like to thank Desart Inc. executive officer Phillip Watkins, Desart Inc. staff Michelle Culpitt, Bronwyn Taylor, Melissa Kramer and Tori Reid, Jane Young (former chair, Desart Inc.); Tim Acker (Aboriginal and Torres Strait Islander Art Economies project CRC REP); Phillipa Roberton, Sudiipta Dowsett, Rachael Kiang and Chrysi Lionis (NIEA/COFA/UNSW); Els van Leeuwen, Robyn Maher, Sabrina Talarico and Franca Barraclough. For further information on the Same but Different forums see: <http://www.niea.unsw.edu.au/events/forum-same-differentexperimentation-and-innovation-desert-arts-ii>and Finnane (2013). For further information on the Desert Animations program see <http://www.niea.unsw.edu.au/events/screening-desert-animations $>$.

In 2015 Same but Different expanded to include a national exhibition, artist-in-residency program (Cicada Press, UNSW) and a symposium held at Galleries UNSW/NIEA/UNSW Art \& Design, Sydney. Under the title 'We are in Wonder LAND: New Experimental Art from Central Australia', the exhibition runs 15 May - 15 August 2015, with a one-day public symposium on 16 May. For more information see $<$ http://www.niea.unsw.edu.au/events/we-are-wonder-land-new-experimental-art-central-australiaexhibition> (program). 'We are in Wonder LAND' is a partnership between Desart Inc. and NIEA, with support from the Australia Council and the Australian Research Council.

\section{-NOTES}

${ }^{1}$ Yarljyirrpa (Clever People), Same but Different 2012. See Curtis Taylor this volume for full profile and direct link to Yarljyirrpa (Clever People) 2012.

2 This question mirrors that of Terry Smith (in 'Second Person/First Peoples: Writing about Postcolonial Art', Art Monthly Australia, vol. 64, October 1993, pp. 8-11) who asked, two decades ago, 'Can art writing match the challenges coming from the art itself'? John Carty (in 'The Limits of Criticism', Artlink Indigenous, vol. 33, no. 2, 2013, pp. 54-9) has posed a recent similar demand in relation to (the lack) of adequate art analysis of contemporary abstract acrylic Jukurrpa paintings.

3 The list here would be long. Notably, for Central and Western Desert experimental arts: the 2005 NATSIAA Award to Tjanpi for their life-size, grass-sculpted Toyota; the 2010 WA Art Award for Most Promising New Artist to June Walkutjkurr Richards for works of acrylic 'graffiti'; the 2013 3D NATSIAA prize to Rhonda Sharpe's soft sculptures of Yarrenyty Arltere Artists; national exhibitions include the NGA Tactility (2003); NMA Canning Stock Route/Yiwarra Kuju (2011); Warakurna: All the Stories got into our Minds and Eyes History Paintings (2013), Kungkarangkalpa: Seven Sisters (2013), We Don't Need A Map (Martumili Artists 2012-15); Big hART's Ngapartji Ngapartji, Namatjira and Hip Bone Sticking Out; and MCA String Theory (2013). Publications include Rockchild (1999) Bush Toys; Eickelkamp (1999) Don't Ask for Stories; Warburton Arts Project (2002) Mission Times in Warburton; 
Tjanpi Desert Weavers (2012) and Warnayaka Arts: Digital Arts of the Desert (2013). Smaller and regional exhibitions of experimental works are on the increase, including significant exhibitions at Fremantle Art Centre, Aboriginal and Pacific Art (Sydney), Merenda Gallery (Perth), Outstation (Darwin), Raft (Alice Springs), Gabrielle Pizzi (Melbourne) and The Art Centre Gold Coast. 4 Nicholas Rothwell, 'Fragile Picture of Future', The Australian, 9 August, 2013.

5 Amos Aikman, 'Millions Made from Selling Fakes', The Australian, 26 January 2015; Amos Aikman, 'More Artists Added to List of Suspect Aboriginal Art Sales', The Australian, 27 January 2015; Amos Aikman, 'Auction House Owns Studio and Runs Indigenous 'Alliance', The Australian, 29 January 2015; Amos Aikman, 'Police in Four States, ACCC Field Arthouse Claims', The Australian, 30 January 2015. 6 In Ian McLean, How Aborigines Invented the Idea of Contemporary Art: 1980-2006, Power Publications and the Institute of Modern Art, Sydney, 2011, p. 302.

7 Wanta Steve Jampijinpa Patrick, in Wanta Steve Jampijinpa Patrick, M. Holmes, and L.A. Box, 'NgurraKurlu: A Way of Working with Warlpiri People', Desert Knowledge CRC Report no 41, 2008.

8 Tony Fry and Anne-Marie Willis, 'Aboriginal Art: Symptom or Success', Art in America, vol. 77, July 1989, pp 109-16, 159-60, 163; Faye Ginsburg, 'Screen Memories: Resignifying the Traditional in Indigenous Media', in F. Ginsburg, L. Abu-Lughod and B Larkin (eds), Media Worlds: Anthropology on New Terrain, University of California Press, Berkeley, Los Angeles and London, 2002, pp. 35-57; Eric Michaels, Bad Aboriginal Art: Media, Tradition and Technological Horizons, Allen \& Unwin, Sydney, 1994; James Weiner, 'Televisualist Anthropology: Representation, Aesthetics, Politics', Current Anthropology, vol. 38, no. 2, 1997, pp. 197-236.

9 For the acrylic painting movement see Vivien Johnson, Michael Nelson Jagamara, Craftsman House, Sydney, 1997; Fred Myers, Painting Culture: The Making of an Aboriginal High Art, Duke University Press, Durham and London, 2002; Jennifer Biddle, Breasts, Bodies, Canvas: Aboriginal Art as Experience, UNSW Press, Sydney, 2007. For Indigenous filmmaking, see Michaels, Bad Aboriginal Art; Marcia Langton, Well I Heard It on the Radio and I Saw It on the Television, Australian Film Commission, Sydney, 1993; Faye Ginsburg, 'Rethinking the Digital Age' in D. Hesmondhalgh, and J. Toynbe (eds), The Media and Social Theory Reader, Routledge, New York, 2008, pp. 129-44.

10 Inge Kral, Talk, Text and Technology: Literacy and Social Practice in a Remote Indigenous Community, Multilingual Matters Ltd, Bristol, 2012; Ginsburg, 'Rethinking the Digital Age'.

11 Philip Watkins in Jeremy Eccles, 'NATSIAAS Refreshed' Aboriginal Art Directory

< http://news.aboriginalartdirectory.com/tags/NATSIAAs> (accessed 13 September 2013).

12 Shelly Errington, The Death of Authentic Primitive Art and Other Tales of Progress, University of California Press, Berkeley, 1998.

${ }^{13}$ See Davenport Acker this volume; Jennifer Biddle, 'Making (not taking) History: Yiwarra Kuju The Canning Stock Route', Art Monthly, no. 252, August 2012.

14 Faye Ginsburg and Fred Myers, 'A History of Indigenous Futures: Accounting for Indigenous Art and Media', Critique of Anthropology, vol. 26, no. 1, 2006, pp 27-45. 
15 Jennifer Biddle, 'A Politics of Proximity: Tjanpi and other Experimental Western Desert Art', Studies in Material Thinking, vol. 8, no. 12, 2012, pp 1-15.

16 Jennifer Biddle, 'Art Under Intervention: The Radical Ordinary of June Walkujukurr Richards', Art Monthly, no. 227, March 2010, pp 35-9; Biddle, 'A Politics of Proximity'; Jennifer Biddle, Remote AvantGarde: Aboriginal Art under Occupation (forthcoming, Duke University Press); Lisa Stefanoff, 'CCAAMA Productions: Listening, Revelation and Cultural Intimacy at the Central Australian Aboriginal Media Association', PhD thesis, New York University, 2009.

17 Paul Toohey, 'Last Drinks: The Impact of the Northern Territory Intervention', Quarterly Essay, no.

30, June 2008; Louis Nowra, Bad Dreaming: Aboriginal Men's Violence against Women and Children, Pluto Press, Melbourne, 2007; Peter Sutton, The Politics of Suffering: Indigenous Australia and the End of Liberal Consciousness, Melbourne University Press, Melbourne, 2009.

18 Tim Acker, Lisa Stefanoff and Alice Woodhead, Aboriginal and Torres Strait Islander Art Economies Project: Literature Review, CRC-REP Working Paper CW010, Ninti One Limited, Alice Springs, 2013.

${ }^{19}$ Same But Different was first conceived within, and is supported by, an Australian Research Council (ARC) Future Fellowship, Jennifer Biddle, 'Remote Avant-garde: Experimentation in Indigenous Arts', NIEA/COFA/UNSW 2010-2014. In 2013 some artists were supported to attend Same but Different through Arts NT and Country Arts WA grants.

20 Jacques Ranciere, 'The Emancipated Spectator', ArtForum, vol. 45, no. 7, March, 2007, p. 280.

21 Pearson said: 'I'm just bitterly disappointed to hear this deranged debate go on in the sub-standard manner in which it's being conducted',

<http://www.abc.net.au/worldtoday/content/2015/s4195263.htm>.

\section{-BIBLIOGRAPHY}

Acker, T., L. Stefanoff and A. Woodhead, Aboriginal and Torres Strait Islander Art Economies Project: Literature Review, CRC-REP Working Paper CW010, Ninti One Limited, Alice Springs, 2013.

Aikman, A., 'Auction House Owns Studio and Runs Indigenous “Alliance”', The Australian, 29 January 2015;

Aikman, A., 'Millions Made from Selling Fakes', The Australian, 26 January 2015.

Aikman, A., 'More Artists Added to List of Suspect Aboriginal Art Sales', The Australian, 27 January 2015.

Aikman, A., 'Police in Four States, ACCC Field Arthouse Claims', The Australian, 30 January 2015.

Biddle, J., 'A Politics of Proximity: Tjanpi and other Experimental Western Desert Art', Studies in Material Thinking, vol. 8, no. 12, 2012.

Biddle, J., 'Art Under Intervention: The Radical Ordinary of June Walkujukurr Richards', Art Monthly, no. 227, March 2010

Biddle, J., 'Making (not taking) History: Yiwarra Kuju The Canning Stock Route', Art Monthly, no. 252, August 2012. 
Biddle, J., Breasts, Bodies, Canvas: Aboriginal Art as Experience, UNSW Press, Sydney, 2007.

Biddle, J., Remote Avant-Garde: Aboriginal Art under Occupation (forthcoming, Duke University Press)

Carty. J., 'The Limits of Criticism', Artlink Indigenous, vol. 33, no. 2, 2013.

Eccles, J., 'NATSIAAS Refreshed' Aboriginal Art Directory

$<$ http://news.aboriginalartdirectory.com/tags/NATSIAAs $>$.

Errington, S., The Death of Authentic Primitive Art and Other Tales of Progress, University of California Press, Berkeley, 1998.

Fry, T., and A-M. Willis, 'Aboriginal Art: Symptom or Success', Art in America, vol. 77, July 1989.

Ginsburg, F. and F. Myers, 'A History of Indigenous Futures: Accounting for Indigenous Art and Media', Critique of Anthropology, vol. 26, no. 1, 2006.

Ginsburg, F., 'Rethinking the Digital Age' in D. Hesmondhalgh, and J. Toynbe (eds), The Media and Social Theory Reader, Routledge, New York, 2008. doi: http://dx.doi.org/10.1215/9780822388692$\underline{020}$

Ginsburg, F., 'Screen Memories: Resignifying the Traditional in Indigenous Media', in F. Ginsburg, L. Abu-Lughod and B. Larkin (eds), Media Worlds: Anthropology on New Terrain, University of California Press, Berkeley, Los Angeles and London, 2002.

Ginsburg, F., L. Abu-Lughod and B. Larkin (eds), Media Worlds: Anthropology on New Terrain, University of California Press, Berkeley, Los Angeles and London, 2002.

Hesmondhalgh, D. and J. Toynbe (eds), The Media and Social Theory Reader, Routledge, New York, 2008.

Johnson, V., Michael Nelson Jagamara, Craftsman House, Sydney, 1997.

Kral, I., Talk, Text and Technology: Literacy and Social Practice in a Remote Indigenous Community, Multilingual Matters Ltd, Bristol, 2012.

Langton, M., Well I Heard It on the Radio and I Saw It on the Television, Australian Film Commission, Sydney, 1993.

McLean, I., How Aborigines Invented the Idea of Contemporary Art: 1980-2006, Power Publications and the Institute of Modern Art, Sydney, 2011.

Michaels, E., Bad Aboriginal Art: Media, Tradition and Technological Horizons, Allen \& Unwin, Sydney, 1994.

Myers, F., Painting Culture: The Making of an Aboriginal High Art, Duke University Press, Durham and London, 2002. doi: http://dx.doi.org/10.1215/9780822384168

Nowra, L., Bad Dreaming: Aboriginal Men's Violence against Women and Children, Pluto Press, Melbourne, 2007.

Patrick, W.S.J., M. Holmes and L.A. Box, Ngurra-Kurlu: A Way of Working with Warlpiri People, Desert Knowledge CRC Report, no. 41, 2008.

Ranciere, J., 'The Emancipated Spectator', ArtForum, vol. 45, no. 7, March, 2007.

Rothwell, N., 'Fragile Picture of Future', The Australian, 9 August 2013. 
Smith, T., 'Second Person/First Peoples: Writing about Postcolonial Art', Art Monthly Australia, vol. 64, October 1993.

Stefanoff, L., 'CCAAMA Productions: Listening, Revelation and Cultural Intimacy at the Central Australian Aboriginal Media Association', PhD thesis, New York University, 2009.

Sutton, P., The Politics of Suffering: Indigenous Australia and the End of Liberal Consciousness, Melbourne University Press, Melbourne, 2009.

Toohey, P., 'Last Drinks: The Impact of the Northern Territory Intervention', Quarterly Essay, no. 30, June 2008.

Weiner, J., 'Televisualist Anthropology: Representation, Aesthetics, Politics', Current Anthropology, vol. 38, no. 2, 1997. doi: http://dx.doi.org/10.1086/204605 